\title{
Status of cattle and buffalo farming in Banepa, Panchkal, Panauti of Kavrepalanchock district, Nepal
}

\author{
S. Gautam ${ }^{1}$, N. Neupane ${ }^{1}$, B. Dhital ${ }^{1}$, H. Neupane ${ }^{2}$, and S.P. Bhatta ${ }^{3}$
}

\author{
${ }^{1}$ Department of Livestock Production and Management, ${ }^{2}$ Department of Agricultural Economics, Department of \\ Animal Breeding, , Institute of Agriculture and Animal Science, Tribhuvan University, Rampur Campus, Rampur \\ Nepal \\ "Corresponding author Email: gautamsuraj41@gmail.com
}

Journal of Livestock Science (ISSN online 2277-6214) 12: 125-131

Received on 01/02/21; Accepted on 17/3/21; Published on 28/3/21

doi. 10.33259/JLivestSci.2021.125-131

\begin{abstract}
Livestock farming is traditional farming practice among Nepali farmers as an integrated farming with agriculture. Cattle and Buffalo farming has emerged as an important source of livelihood, which plays significant role in generating gainful employment and income generation opportunities, particularly among the landless, small, marginal farmers and women of rural sector, thus ensures regular flow of money from urban to rural areas which support the food and nutrition security at household level of rural and urban areas. Random purposive sampling technique household survey was conducted among 122 livestock farmers in Panauti, Banepa and Panchkhal Municiplity of Kavrepalanchock district of Nepal. The study was based on the quantitative as well as qualitative data. The results showed that family with more number of females could reap better production. Cattle and buffalo farming's efficiency was found to be high among the farmers where care and management of animals was performed mostly by females however, $98 \%$ of females were involved in tedious task on livestock production. Improved housing system, higher the years of experience, roughages with added legumes, concentrate with added oilcakes, timely and proper medicinal services had positive impact in increasing production efficiency. Labour cost (52.37\%) was the major cost component in total variable cost followed by feed cost $(22.44 \%)$.The study found that total cost of production, annual income, net return, gross return was more in buffalo farming than mixed farming of cattle and buffalo. B/C ratio of buffalo farming (1.36) was higher than mixed farming of cattle and buffalo (1.27), and cattle farming (1.25). Besides being preferred occupation by farmers, cattle and buffalo farming suffers from a lot of problems; high production cost, insecure market, shortage of feeds and fodder, high incidence of diseases, lack of skilled manpower and quality technical services. Farmers with women visibility need to be motivated to start the professional livestock farming of focusing on the increase in income.
\end{abstract}

Key-words: Buffaloes; Cattle; Cost; Dairy Farming; Nepal 


\section{Introduction}

Cattle and buffalo population is increasing. Similarly, growth rate of milk was accelerated from $1.72 \%$ to $3.09 \%$ per annum and out of total milk production, $70 \%$ comes from buffaloes and $30 \%$ from cattle. Whereas, the deficit milk is imported mostly from India in Nepal (MoAD, 2017). Cattle and buffalo farming has emerged as an important source of generating gainful employment in rural sector, particularly among the landless, small and marginal farmers which form an important livelihood activity who are supporting agriculture in the form of business. Cattle and buffalo farmers are struggling with lower milk production per cattle and buffalo in Nepal (Kam, 2017). This research was therefore performed with the aim to identified and addressed problems, access the production status, know the factors affecting production efficiency and economic analysis with the profitability of the production process of cattle and buffalo farming.

\section{Materials and methods}

Kavrepalanchok district, with Dhulikhel as its district headquarters, covers an area of $1,396 \mathrm{~km}^{2}$ and has a population of 381,937 . Kavrepalanchok consists lower tropical climate zone in $0.1 \%$ of area which is below 300 meters, upper tropical climate zone in $23.6 \%$ of area which is 300 to 1000 meters, Sub tropical climate zone in 65.3 $\%$ of area which is 1000 to 2000 meters and temperate climate zone in $9.6 \%$ of area which is 2000 meters to 3000 meters. Likewise, it's geo-coordinates is $27^{\circ} 37^{\prime} 12^{\prime \prime} \mathrm{N}, 85^{\circ} 33^{\prime} 0^{\prime \prime}$ E. Kavrepalanchok district had 71,598 and 66,252 total numbers of cattle and buffalo population. Similiarly, annual growth rate of cattle and buffalo population were 1.03 percent and 6.98 percent. Also, annual growth rate of milk production was 25.64 percent. The annual growth rate of cow and buffalo milk production in Kavre were 9.71 percent and 29.52 percent. 4.58 percent of total milk is produced from Kavre district in Nepal (MoAD, 2017). The research site was Kavre district in 2019 because it has become the first district to become self-sufficient in dairy produce (Guragain, 2016).

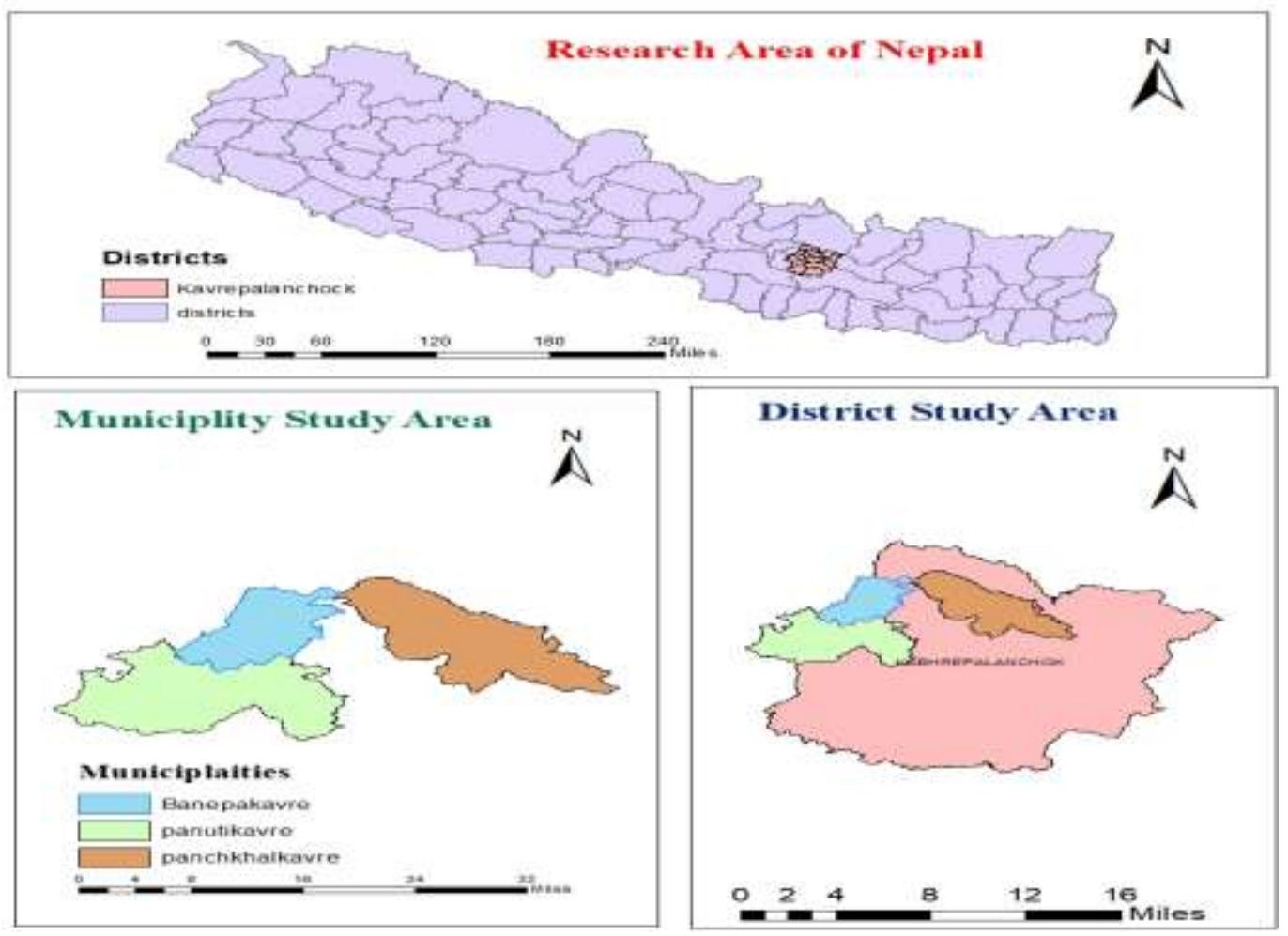

Fig 1. Geopolitical map of Kavrepalanchok of Nepal

Pilot study was conducted to gather the preliminary information. Questionnaire was prepared which consisted of sociodemographic characteristics, institutional access of farmers and farming practices, diseases or 
disorders, constraints and production of cattle and buffalo. The random sample were selected among the farmers who were rearing cattle and buffalo. The primary and secondary data was collected and it was coded first, tabulated, and entered. Microsoft excel spread sheet, Statistical Package for Social Science (SPSS), and STATA were used for analysis of data. From that sample frame, 42 farmers were from Panchkhal, 40 farmers were from Banepa, 40 farmers were from Panauti. A total of 122 samples of cattle and buffaloes farmers were selected from Kavre district. Socio demographic characteristics, institutional aspects, farm practices, production of cattle and buffalo were analyzed descriptively. A multiple regression analysis was performed by taking variables like milk yield per lactation and lactation length as dependent variables whereas, independent variables were different sociodemographic characteristics, farming practices. A Stochastic frontier analysis was performed by taking variables like number of male and female population in household, level of experience and education, quantity of feed stuffs, impacts of training and programs and livestock Unit showing its effects in milk production per lactation. Farmer perception to different diseases, disorders and constraints were analyzed and ranked on the basis of responses frequencies. Economic analysis was access along with the profitability of the production process.

\section{Results and discussion}

Majority were smallholder farmers with some medium sized and few large scale producers with mean dairy herd size of 4.7. Figure 1 shows that, herd size of dairy livestock comprised $62 \%$ milking animal, $28 \%$ Calf / Heifers and $10 \%$ dry animals respectively in study sites.

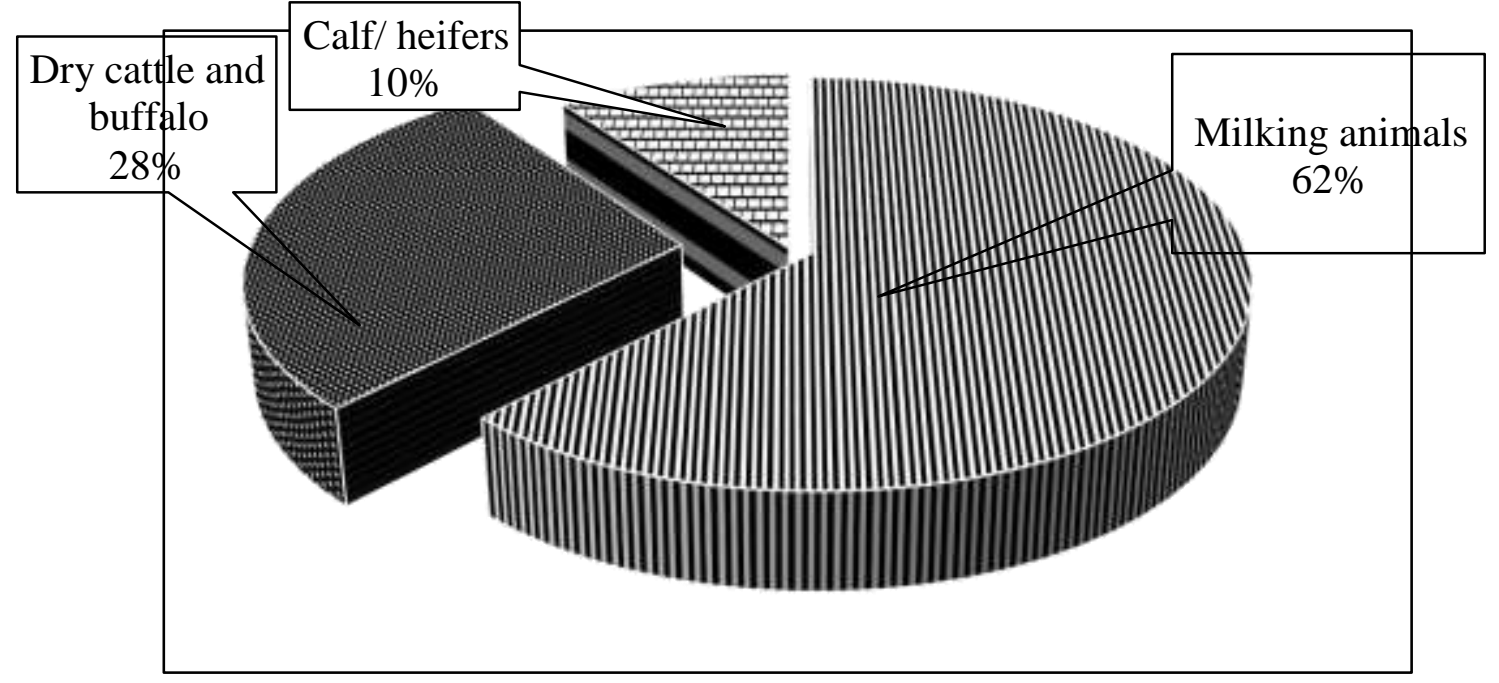

Fig 2. Herd composition of dairy livestock per household

Commercial oriented framers mostly followed conventional housing system while small scale farmers raised in intensive system where small scale farmers mostly practice mixed traditional farming system and tie-stall feeding system with complete integration of crops, livestock and forest resources. In concentrate, maize was the main feed ingredient followed by rice bran, wheat bran, soybean meals, mustard cake, sunflower cake and other legumes byproducts. Vitamins and minerals were provided when the cattle and buffaloes were weak and during milking stage. AI breeding method was highly used then natural breeding method in study areas. Figure 2 reveals that, womens were supposed to work in most of the difficult tasks like forage collection and carriage, cleaning the gutter/sheds and feeding animals whereas mens were involved relatively in easier and attractive tasks of such as milking animals and selling of milk in study sites. Poudel et al. (2009) reported that, 70-90\% of livestock -related works such as forage collection, cleaning the gutters and sheds, and feeding animals performed by women; whereas milking animals is mainly performed by both women and men, and the selling of milk to generate cash income is considered to be the men's domain and higher women's involvement in livestock management as compared to men's; mostly involved in difficult tasks such as forage collection and grass cutting (Karki, 2014). 


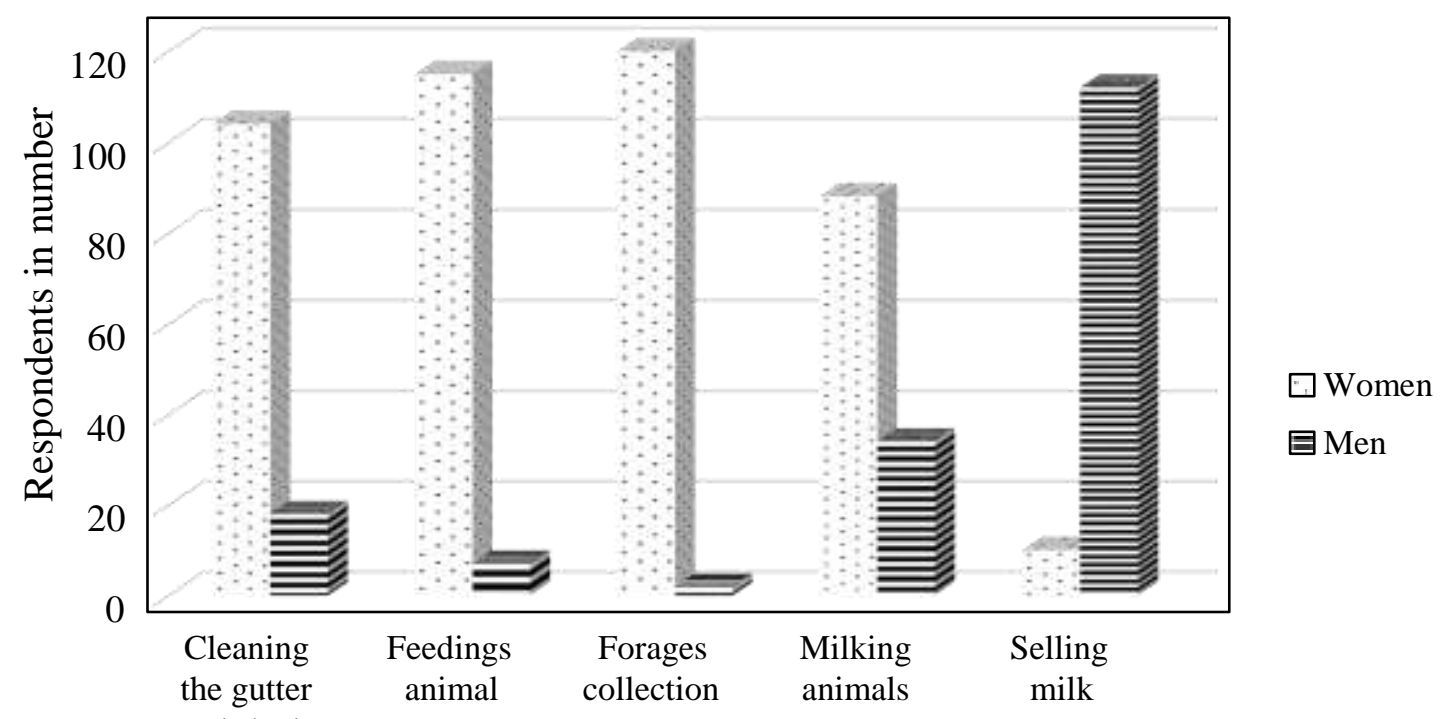

Activities

Fig 2. Different activities performed by different gender for cattle and buffalo farming

As from table 1, cattle had an average milk yield per lactation of $1800 \mathrm{lt}$ with an average lactation period of 300 days whereas, buffalo had an average milk yield per lactation of $1300 \mathrm{lt}$ with an average lactation period of 320 days in study sites. Farmers are struggling with lower milk production per cattle and buffalo (Kam, 2017).

Table 1. Milk production and lactation length of cattle and buffalo

\begin{tabular}{|c|c|c|}
\hline Livestock & Milk production (litres / Lactation) & Lactation length (days) \\
\hline Cattle & 1800 & 300 \\
\hline Buffalo & 1300 & 320 \\
\hline
\end{tabular}

Table 2 shows that that there is significant effect of roughages, concentrates, minerals, vitamins and feed additives, improved housing system, cultivation of fooder crops, vaccination and deworming on milk yield per lactation and lactation length in study sites. Scarce and poorquality food resources limit smallholder dairy production (Muinga et al., 1992). Increasing the total amount of concentrate offered which resulted in increased milk production (Jha, 2002). The effect of mineral supplementation containing per lactation period mixed with Khole on milk yield in buffaloes was found to be significant (Shrestha, 1992). Quality of dairy cows was greatly influenced by the housing system, and that the loose system was more advantageous when it comes to the feeding, housing and behaviour of the dairy cow. Vaccination was vital in promoting both animal health and animal welfare (Morton, 2007). Anti-parasitic treatment in cattle had positive effects on milk yield (Thapa et al., 2019). 
Table 2. Effect of different variables on milk production and lactation length

\begin{tabular}{|l|c|c|c|c|}
\hline \multirow{2}{*}{ Variables } & \multicolumn{3}{|l|}{ Milk production (lt/day) } & \multicolumn{2}{|c|}{ Lactation length } \\
\cline { 2 - 5 } & $\mathrm{B}$ & $\mathrm{Sig}$ & $\mathrm{B}$ & $\mathrm{Sig}$ \\
\hline Roughages ( kg/day/milch animal ) & .096 & .002 & 4.250 & .000 \\
\hline Concentrates ( kg/day/milch animal ) & .011 & .004 & 2.724 & .003 \\
\hline Minerals, vitamins & .238 & .000 & 3.194 & .004 \\
\hline Housing system & .032 & .008 & 1.420 & .000 \\
\hline Cultivation of fodder crops & .018 & .000 & 2.590 & .001 \\
\hline Vaccination and deworming programmes & .037 & .000 & 2.380 & .000 \\
\hline $\mathrm{R}^{2}$ Value & 0.675 & & \multicolumn{2}{|c|}{0.81} \\
\hline
\end{tabular}

$\mathrm{B}$ "+" shows positive relation and $\mathrm{P}>0.05$ gives significant effect.

Table 3 findings showed higher the number of male members in family has non-significant effect on production efficiency while higher the number of female members in family higher is the production efficiency. Women's economic activity is still low in non-agriculture sectors. Naturally, women engaged in self-employment activities or unpaid family labour is very high. Participation in training has non-significant effect in production efficiency. This might be because trainings are not provided as per need of the farmers. Improved housing system has positive impact in increasing production efficiency. Higher the years of experience in farming more is the production efficiency. The total milk yield of the medium size herd was significantly greater than the herd size for small and large size herd (Abdelgawad, 2017).

Table 3. Production efficiency on milk production per lactation

\begin{tabular}{|c|c|c|c|c|}
\hline \multirow[t]{2}{*}{ Variables } & \multicolumn{2}{|c|}{ Cattle ( lt/lactation) } & \multicolumn{2}{|c|}{ Buffalo(lt/lactation) } \\
\hline & Coefficient & Std. Error & Coefficient & Std. Error \\
\hline Schooling year of household head & 0.002 & 0.003 & 0.473 & 0.204 \\
\hline Number of Males (15-60 yrs) & -0.023 & 0.005 & -0.083 & 0.086 \\
\hline Number of Female (15-60 yrs) & $0.066^{* * *}$ & 0.004 & $0.193 * * *$ & 0.124 \\
\hline Housing system & $0.054 * *$ & 0.011 & $1.395 * *$ & 0.052 \\
\hline Farming experience & $0.009 * *$ & 0.001 & $0.040 * *$ & 0.019 \\
\hline Concentrates ( kg/day/milch animal ) & $0.029 * *$ & 0.011 & $0.377 * *$ & 0.166 \\
\hline Roughages ( kg/day/milch animal ) & $0.023 * *$ & 0.038 & $0.052 * *$ & 0.010 \\
\hline Minerals and Vitamins & $0.009 * *$ & 0.045 & $0.028 * *$ & 0.125 \\
\hline Participation in Training programs & $0.000 * *$ & 0.000 & $0.053 * *$ & 0.023 \\
\hline LSU & $0.026 * * *$ & 0.004 & $0.141 * *$ & 0.067 \\
\hline LSU sq & $-0.001 * * *$ & 0.000 & $-0.010 * * *$ & 0.002 \\
\hline LSU Constant & $7.264 * * *$ & 0.048 & $13.525 * * *$ & 3.166 \\
\hline $\begin{array}{l}\text { Mu who does care and management } \\
\text { (gender) }\end{array}$ & $-17.596 * *$ & 4.870 & $-3.610 * *$ & 1.57 \\
\hline Sigma U & $0.063 * *$ & 3.205 & $0.446 * *$ & 0.101 \\
\hline Sigma V & 0.001 & 1.280 & 0.000 & 0.000 \\
\hline
\end{tabular}

$* * *$ - significant at $1 \%, * *$ - significant at $5 \%, *$ - significant at $10 \%$ level of significance

Figure 5 shows that the highest cost of production was seen from annual labour cost $(52.37 \%)$ which was followed by annual feed cost (22.44\%), depreciated shed cost (8.98\%), depreciated livestock cost (8.48\%), annual medicinal - vet services cost $(6.98 \%)$ and annual other cost (water, electricity, communication charges, equipments etc.) $(0.75 \%)$ respectively in study sites. Labor cost was included by calculating spent hours while collecting fodders. Table 4 shows that total cost of production, annual income, net return, gross return was more in buffalo farming than mixed farming of cattle and buffalo, cattle farming. B/C ratio of buffalo (1.36) was high than mixed farming of cattle and buffalo (1.27), cattle (1.25) farming in a farm of respondent farmers. 


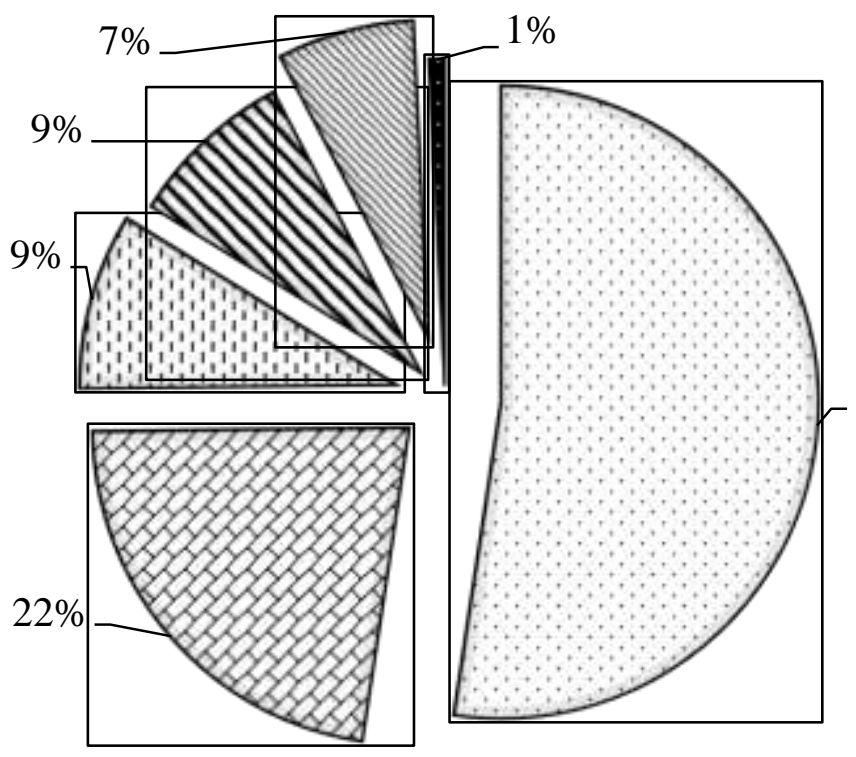

Labor cost

Feed cost

Shed cost

$52 \%$-ivestock cost

Medicinal and Vet

services

Equipment and other cost

Figure 3. Annual production cost percentages

Total cost of production, annual income, net return and gross return was more in buffaloes than cow (Kumawat \& Singh, 2014; Sharma \& Singh, 2020). Buffalo is multi-purpose livestock. So, Benefit- cost ratio of buffalo is higher than cow in small holder farmers (Timilsina, 2010).

Table 4. Annual income, Net return, Gross return and B/C ratio per household

\begin{tabular}{|c|c|c|c|c|l|}
\hline Livestock & $\begin{array}{c}\text { Total cost of } \\
\text { production } \\
\text { (NRs/household) }\end{array}$ & $\begin{array}{c}\text { Annual income } \\
\text { (NRs/household) }\end{array}$ & $\begin{array}{c}\text { Net return } \\
\text { (NRs/household) }\end{array}$ & $\begin{array}{c}\text { Gross return } \\
\text { (NRs/household) }\end{array}$ & B/c ratio \\
\hline Cattle & 207500 & 260000 & 52500 & 78500 & 1.25 \\
\hline Buffalo & 217900 & 297000 & 79100 & 115100 & 1.36 \\
\hline Mixed & 212700 & 270129 & 57429 & 88429 & 1.27 \\
\hline
\end{tabular}

Table 4 reveals that there is high significant effect of economic active females, whereas, significant effect of vaccination and deworming programs, livestock unit. Also, there was positive impacts of cultivation of crops, roughages, concentrates, minerals and vitamins but negative impact of economic active males on B/C ratio in study sites.

Table 5. Effect of different variables on $\mathrm{B} / \mathrm{C}$ ratio in a farm of respondents

\begin{tabular}{|l|c|c|}
\hline Variables & Coefficient & Std. Error \\
\hline Number of Males (15-60 yrs)/household & -0.034 & .048 \\
\hline Number of Females (15-60 yrs)/household & $0.071^{* * *}$ & .053 \\
\hline Housing system & 0.129 & .140 \\
\hline Cultivation of crops & 0.115 & .100 \\
\hline Vaccination and deworming programs & $0.164^{* *}$ & .081 \\
\hline Concentrates ( kg/day/milch animal ) & 0.003 & .018 \\
\hline Roughages ( kg/day/milch animal ) & 0.015 & .057 \\
\hline Minerals and Vitamins & 0.016 & .019 \\
\hline LSU & $0.014^{* *}$ & .015 \\
\hline $\mathrm{R}^{2}$ Value & 0.61 & \\
\hline
\end{tabular}

$* * *$ - significant at $1 \%, * *$ - significant at 5\%, *-significant at $10 \%$ level of significance 


\section{Conclusion and recommendation}

There were few farmers who had done the farming professionally to increase the earning, otherwise, farmers were doing farming only for their own needs. Farmers felt no any significant changes and improvement in their economic status due to long years of involvement in dairy farming. Major health problems was mastistis followed by stomach disorder, intestine discomfort, diarrhea, loss of appetite, weakness, low immunity and itching whereas, major constraints was lower price of product followed by lack of credit, lack of forages cultivation, unavailability of input in time, poor availability of improved breed and traditional farming techniques in study sites. The identified problems can be improved by providing quality feed and fodder throughout the year, sound health and management practices and selecting appropriate cattle/buffalo breeds for particular regions. The profit margin must be increased, by decreasing the cost of production. The institutional efforts should aim to promote and nurture the grassroots level participatory as per their need. Also, it should encourage and promote adoption of appropriate technologies, enhance productivity, increase effectiveness of small holders, particularly women.

\section{References}

1) Abdelgawad, E.T. 2017. Effect of Herd Size on the Productive, Reproductive, and Economic Efficiency of Holstein Dairy Cows. Alexandria Journal of Veterinary Sciences 55: 21-27

2) Guragain, M.S. 2016. Kavre district declared self-sufficient in milk production. Myrepbulica. Economic Affairs. 61: 71-74.

3) Jha, P.K., R.S. Rana and B.S. Shrestha. 2002. Effect of concentrate supplementation in milk production of lactating buffaloes fed on crop residues based diets. In: Rai AK (ed.), Proceedings of $5^{\text {th }}$ National Workshop on Livestock and Fisheries Research in Nepal, 10-11 July, 2002. National Agriculture Research Council. National Animal Science Research Institute, Khumaltar, Lalitpur, Nepal 31-36.

4) Kam, P.R. 2017. Why farmers cry. Cattle farming in Nepal. Dairy global.

5) Karki, L. 2014. Women's Empowerment and Farm Productivity: A Case of Project Intervention. Country gender assessment of agriculture and the rural sector in Nepal. FAO, UN, Nepal

6) Kumawat, R. and N.K. Singh. 2016. Analysis of cost and returns of milk production in Rajasthan. Economic affairs 61: 71-74

7) MoAD. 2017. Planning and Evaluation Division. GON, Singhadurbar, Kathmandu, Nepal.

8) Muinga, R.W., W. Thorpe and J.H. Topps. 1992. Voluntary food intake, live-weight change and lactation performance of crossbred dairy cows given ad libitum Pennisetum purpureum (napier grass var. Bana) supplemented with leucaena forage in the lowland semi-humid tropics. Cambridge University 55: 331-337.

9) Paudel, L.N., U.T. Meulen, C. Wollny, H. Dahal and M. Gauly. 2009. Gender aspects in livestock farming: pertinent issues for sustainable livestock development in Nepal. Livestock Research for Rural Development. 21: 40-42.

10) Sharma J.K. and Singh N.K. 2020. Economic studies on unorganized dairy farms in Jaipur region of Rajasthan. Journal of Livestock Science 11: 127-132

11) Shrestha NP, Chemjong PB, Shrestha SR, Rai PP, Neupane SP and Khatri BB, 1992. Effect of mineral supplementation on milk yield in buffaloes. Nepal Animal Science Research Institute 8:63-65.

12) Thapa, U., N. Shrestha, S. Adhikari, N. Kafle, M.R. Shrestha, K. Banjara, R. Steneroden, K. R. Bowen, B. Rijal and P. Adhikari. 2019. Effect of deworming on milk production in dairy cattle and buffaloes infected with gastrointestinal parasites in the Kavrepalanchowk district of central Nepal. Vet Record Ope 7(1)

13) Timilsina, K. 2010. Economics of Dairy farming: A case study of Phulbari of Chitwan district of Nepal. Journal of Nepal Agriculture Research Council 40: 55-57 